\title{
Bryophyta (Mosses) of Senegal: the case of Mosses in Herbaria and databases
}

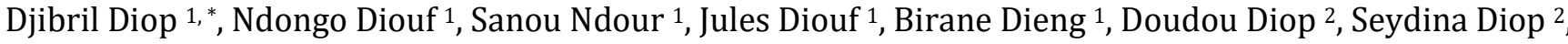 \\ Abdoul Aziz Camara ${ }^{1}$, Mame Samba Mbaye ${ }^{1}$ and Kandioura Noba ${ }^{1}$ \\ ${ }^{1}$ Botany - Biodiversity Laboratory, Department of Plant Biology, Faculty of Science and Technology, Cheikh Anta Diop \\ University, BP 5005, Dakar-Fann, Senegal. \\ ${ }^{2}$ Fundamental Institute of Black Africa Cheikh Anta Diop (IFAN-CAD) Dakar-Senegal.
}

GSC Biological and Pharmaceutical Sciences, 2021, 17(03), 177-185

Publication history: Received on 17 November 2021; revised on 19 December 2021; accepted on 21 December 2021

Article DOI: https://doi.org/10.30574/gscbps.2021.17.3.0364

\begin{abstract}
In Senegal, Mosses constitute a large and diverse systematic group. This work is a contribution to the knowledge of Bryophyta in the herbaria of Senegal. It specifically proposes to determine the structure of the Bryophyta on the prospected sites in order to provide basic knowledge for a better sustainable management.

This study is carried out in the first place in the herbaria of the University Cheikh Anta Diop of Dakar/Senegal: the herbarium of the Institut Fondamental d'Afrique Noire Cheikh Anta Diop (IFAN) and the herbarium DAKAR of the Department of Plant Biology of the Faculty of Sciences and Techniques. Secondly, a consultation of different checklists and databases was conducted to collect more information.

This research work on the flora of the mosses allowed us to identify a total of 70 species divided into 44 genera, 24 families and 12 orders. The orders Hypnales, Dicranales and Hookeriales are the most represented. Bryaceae are dominant followed by Pottiaceae, Calymperaceae, Dicranaceae and Hypnaceae. The genera Fissidens, Calymperes, Bryum, Gemmabruym and Leucoloma are more diversified.
\end{abstract}

These results are important for the conservation of the environment and the enhancement of plant biodiversity in Senegal.

Keywords: Bryophyta; IFAN; DAKAR herbarium; Biodiversity; Senegal

\section{Introduction}

Bryophytes in the strict sense (Bryophyta) represent about 10,000 [21] to more than 13,000 species [19] in 845-866 genera $[20,12]$ and six classes worldwide. There is growing evidence that mosses are at the highest level of diversity in their evolutionary history [35]. This fairly recent diversification of mosses is probably related to the advent of Angiosperm forests offering a wide range of habitats (the bulk of moss diversity in tropical rainforests). Although mosses are rather small organisms, their morphology is relatively complex. Throughout their evolutionary history, mosses have undergone repeated morphological reduction and simplification [34], often as a result of colonization of specialized, particularly xeric or ephemeral habitats [53]. In Senegal, studies on the floristic diversity of mosses are still at the embryonic stage, despite the presence of samples in the Dakar and IFAN herbaria, two reference herbaria in the field of species conservation. Little information on bryophyte assemblages is available in these herbaria. It also seemed

\footnotetext{
* Corresponding author: Djibril Diop

Botany - Biodiversity Laboratory, Department of Plant Biology, Faculty of Science and Technology, Cheikh Anta Diop University, BP 5005, Dakar-Fann, Senegal. 
important to us to set up valuable tools for knowledge, conservation and decision support for a sustainable management of the species.

The aim of this work is to contribute of Bryophyta in the herbaria of Senegal. It specifically proposes to determine the structure of the Bryophyta on the prospected sites in order to provide basic knowledge for a better sustainable management.

\section{Material and methods}

\subsection{Study site}

The study was carried out in the herbaria of Senegal mainly in the IFAN herbarium and the DAKAR herbarium. Created respectively in 1941 by Professor Paul JAEGER and in 1960 by Professor J. MIEGE, they are reference places in the ex situ conservation of sample collections in Senegal. With as main objective the creation of a bank of all the plant species of French-speaking Africa, then of all continental and insular Africa, the Herbarium of the Institut Fondamental d'Afrique Noire Cheikh Anta Diop (IFAN) is the oldest herbarium in French-speaking Africa, centralizing the main part of the botanical activities in the former French metropolis. While the DAKAR Herbarium, attached to the Department of Plant Biology of the Faculty of Science and Technology of the Cheikh Anta DIOP University of Dakar, its main objective aimed at is to constitute a good quality and representative collection of the flora of Senegal and a remarkable knowledge base in the fields of research, training, knowledge, conservation of plant resources and African and international collaboration [23].

\subsection{Methods}

Visits to the herbarium collections were made to the two large herbaria and databases to establish the floristic list of bryophytes. Scientific names were checked via Tropicos, Plant List or efloras. The classification of [35] was used. The identification of species was possible thanks to different means. Identification keys in Africa: For mosses: the key of [48] can be used, which is also on the Internet, on the site of the Tropical Bryological Group (http://www.nhm.ac.uk/hosted_sites/bbstbg/) and the available African floras: the Flora of the Bryophytes of South Africa [51], the fascicles of the Flora of South Africa [38, 39, 42, 49] and the Flora of Gabon [50]. Other floras have been used to facilitate identification, such as the Bryophyte Flora of Augier [3] and many other papers.

\section{Results}

This floristic list is made up of species reported in the SONNERAT database and checklists from Africa [47, 56] and species from IFAN and DAKAR herbaria. This flora of the Mosses is made up of a total of 70 species divided into 44 genera and 24 families and 12 orders (Tab. 1). The orders Hypnales ( 8 families, 13 genera), Dicranales (4 families, 9 genera) and Hookeriales ( 3 families and 4 genera) are the most represented in this flora in terms of families and genera. The rest are represented by only one family (Tab. 2). In terms of species, Dicranales (24 species), Hypnales (17 species) and Bryales (11 species) are the most represented. In terms of diversity within families, Bryaceae are dominant with six genera and eleven species followed by Pottiaceae (4 genera, 4 species), Calymperaceae (3 genera, 8 species), Dicranaceae (3 genera, 6 species) and Hypnaceae (3 genera, 4 species). For generic diversity, the genera Fissidens ( 8 species), Calymperes (4 species), Bryum (3 species) Gemmabruym (3 species) and Leucoloma (3 species) are more diverse.

Table 1 List of Bryophyta species recorded

\begin{tabular}{|c|c|c|c|}
\hline Orders & & Families & Species \\
\hline \multirow{4}{*}{$\begin{array}{l}\text { Bartramiales } \\
\text { Menzel }\end{array}$} & \multirow{4}{*}{ M. } & \multirow{4}{*}{ Bartramiaceae Schwägr. } & ${ }^{1}$ Philonotis brevicuspis var. peroblusata P. de la Varde \\
\hline & & & $\equiv$ Philonotis brevicuspis var. peroblusata (C.M.) Broth. \\
\hline & & & ${ }^{1}$ Philonotis hastata (Duby) Wijk et Margad. \\
\hline & & & $\equiv$ P. laxissima (C. Müll.) Bryol. Javan \\
\hline \multirow{3}{*}{\multicolumn{2}{|c|}{ Bryales Limpr. }} & \multirow{3}{*}{ Bryaceae Schwägr. } & $\begin{array}{l}\text { Brachymenium leptophyllum (Bruch et Schimp. ex } \\
\text { Müll. Hal.) Bruch et Schimp. ex A. Jaeger }\end{array}$ \\
\hline & & & ${ }^{1}$ Brachymenium wrightii (Sull.) Broth. \\
\hline & & & ${ }^{3}$ Bryum capillare Hedw. \\
\hline
\end{tabular}




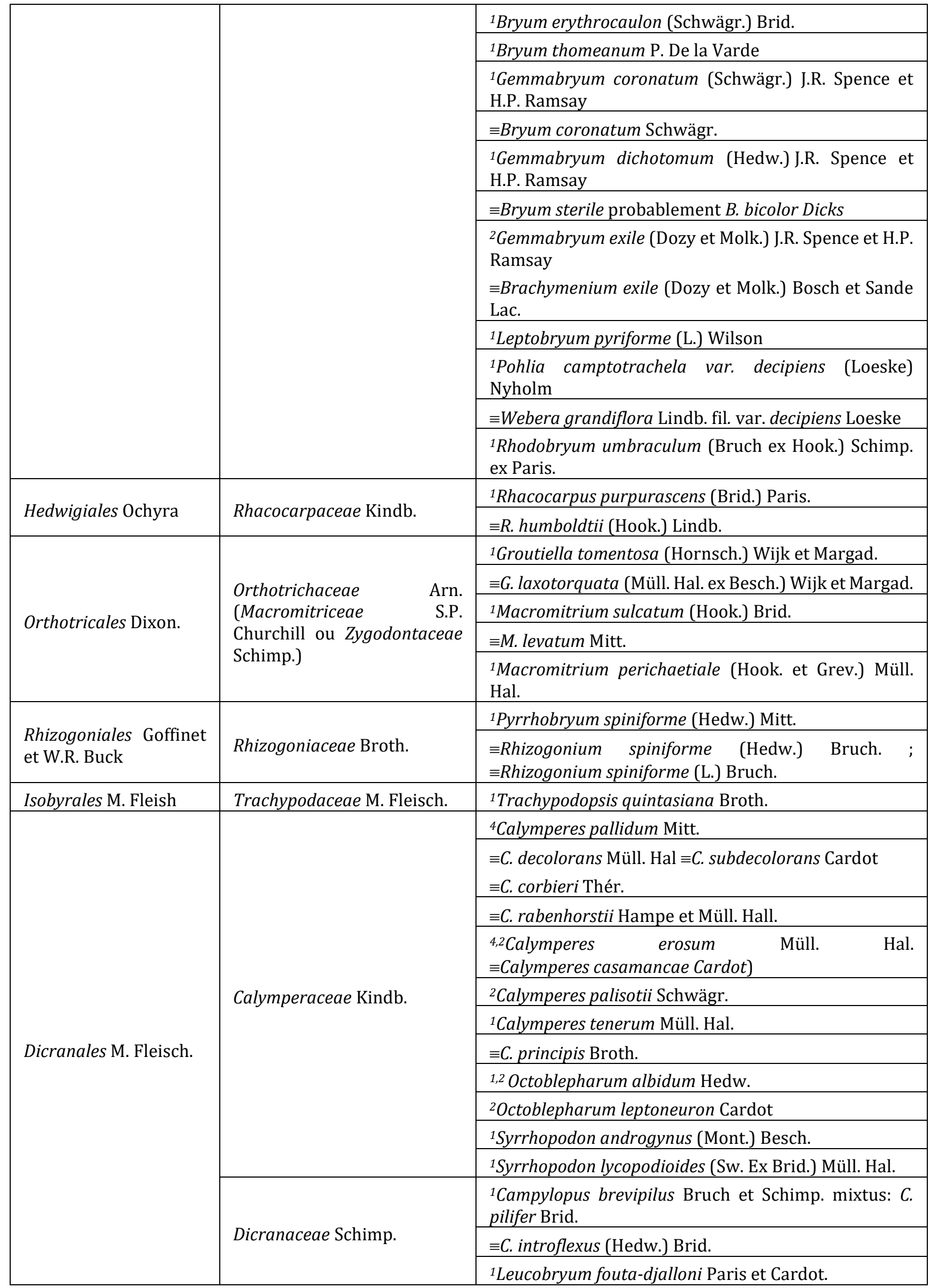




\begin{tabular}{|c|c|c|}
\hline & & ${ }^{1}$ Leucobryum madagassum Bresch. \\
\hline & & ${ }^{1}$ Leucoloma albulum (Sull.) A. Jaeger \\
\hline & & ${ }^{1}$ Leucoloma fuscifolium Besch. \\
\hline & & ${ }^{1}$ Leucoloma serrulatum Brid. \\
\hline & \multirow{3}{*}{ Erpodiaceae Broth. } & $\begin{array}{l}{ }^{2} \text { Erpodium coronatum (Hook.f. et Wilson) Mitt. var. } \\
\text { coronatum }\end{array}$ \\
\hline & & ${ }^{2}$ Venturiella perrottetii (Mont.) Pursell. \\
\hline & & $\equiv$ Erpodium theriotii Broth. in Corb.) \\
\hline & \multirow{10}{*}{ Fissidentaceae Schimp } & 4,2Fissidens intramarginatus (Hampe) A. Jaeger \\
\hline & & $\equiv F$. casamancae Cardot, \\
\hline & & $\equiv$ F. mathieui Cardot \\
\hline & & 4,2Fissidens weirii Mitt. \\
\hline & & $\equiv F$. circinicaulis Cardot \\
\hline & & ${ }^{2}$ Fissidens gardneri Mitt. \\
\hline & & 2,4Fissidens marthae Cardot \\
\hline & & ${ }^{2}$ Fissidens parkii Mitt. \\
\hline & & ${ }^{3}$ Fissidens $s p$ \\
\hline & & 3,2Fissidens submarginatus Bruch ex C. Krauss \\
\hline \multirow{2}{*}{ Funariales M. Fleish } & \multirow{2}{*}{ Funariaceae Schwägr. } & ${ }^{1}$ Funaria hygrometrica Hedw. \\
\hline & & $\equiv$ F. hygrometrica (L.) Sibth. \\
\hline \multirow{6}{*}{ Hookeriales M. Fleish } & \multirow{2}{*}{ Daltoniaceae Schimp. } & ${ }^{1}$ Lepidopilum lastii Mitt. \\
\hline & & $\equiv$ L. callochlorum C.M. (C. Juv. Spg.) \\
\hline & \multirow{3}{*}{ Hookeriaceae Schimp. } & ${ }^{1}$ Harpophyllum aureum (Lam. ex Brid.) Spruce \\
\hline & & $\equiv$ H. aureum (P.B.) Spr. \\
\hline & & ${ }^{1}$ Hookeriopsis acicularis (Mitt.) A. Jaeger. \\
\hline & Pilotrichaceae Kindb. & ${ }^{1}$ Callicostella fissidentella (Besch.) Broth. \\
\hline \multirow{18}{*}{$\begin{array}{l}\text { Hypnales W. R. Buck et } \\
\text { Vitt. }\end{array}$} & Amblystegiaceae Kindb. & ${ }^{1}$ Campylium chrysophyllum (Brid.) Loeske \\
\hline & \multirow{4}{*}{ Hypnaceae Schimp. } & ${ }^{1}$ Ectropothecium brevifalcatum (Müll. Hall) Kindb. \\
\hline & & ${ }^{1}$ Ectropothecium perrotii Renault et Cardot \\
\hline & & ${ }^{1}$ Gollania monodii P. de la Varde. \\
\hline & & ${ }^{1}$ Vesicularia scaturigina (Brid.) Broth. \\
\hline & \multirow{3}{*}{ Meteoriaceae Kindb. } & ${ }^{1}$ Floribundaria patentissima (Müll. Hal.) M. Fleisch. \\
\hline & & $\begin{array}{l}{ }^{1} \text { Orthostichella versicolor (Müll. Hal.) B. H. Allen et W. } \\
\text { R. Buck }\end{array}$ \\
\hline & & $\equiv P$. communis C.M. \\
\hline & \multirow{5}{*}{ Neckeraceae Schimp. } & ${ }^{1}$ Porotrichum mutabile Hampe \\
\hline & & $\equiv P$. insularum Mitt. \\
\hline & & ${ }^{2}$ Porotrichum substriatum (Hampe) Mitt. \\
\hline & & $\equiv P$. caudatum Broth. \\
\hline & & ${ }^{1}$ Pinnatella piniformis (Brid.) M. Fleisch. \\
\hline & \multirow{3}{*}{ Pterigynandraceae Schimp. } & ${ }^{2}$ Trachyphyllum dusenii (Müll. Hal. ex Broth.) Broth. \\
\hline & & $\equiv$ Trachyphyllum dusenii (Broth.) Broth. \\
\hline & & ${ }^{2}$ Trachyphyllum gastrodes (Duby) A. Gepp in Hiern \\
\hline & Pterobryaceae Kindb. & ${ }^{1}$ Orthostichidium perpinnatum (Broth.) Dusén \\
\hline & Sematophyllaceae Broth. & ${ }^{1}$ Taxithelium subrotundatulum Broth. et Paris \\
\hline
\end{tabular}




\begin{tabular}{|c|c|c|}
\hline & \multirow{3}{*}{ Thuidiaceae Schimp. } & ${ }^{1}$ Pelekium cf. varians (Welv. et Duby) A. Touw. \\
\hline & & 2,3Pelekium gratum (P. Beauv.) Touw \\
\hline & & ${ }^{3}$ Thuidium sp \\
\hline \multirow{2}{*}{ Polytrichales Cavers } & \multirow{2}{*}{ Polytrichaceae Schwägr. } & ${ }^{1}$ Pogonatum gracilifolium Besch. \\
\hline & & $\equiv P$. rubentiviride (Müll. Mal) Paris \\
\hline \multirow{8}{*}{ Pottiales M. Fleish } & \multirow{8}{*}{ Pottiaceae Hampe } & ${ }^{1}$ Barbula afrofontana (Müll. Hal) Broth. \\
\hline & & ${ }^{1}$ Eucladium verticillatum (With.) Bruch et Schimp. \\
\hline & & $\equiv$ E. verticillatum (L.) B.E.) \\
\hline & & ${ }^{1}$ Hyophila involuta (Hook.) A. Jaeger \\
\hline & & $\equiv$ H. atrovirens (Rehmann ex Müll. Hal.) Broth. \\
\hline & & $\equiv$ H. atrovirens (Besch.) Broth. \\
\hline & & ${ }^{1}$ Morinia ehrenbergiana (Müll. Hal.) Thér. \\
\hline & & $\equiv$ Barbula ehrenbergii (Lorentz) M. Fleisch. \\
\hline
\end{tabular}

Table 2 Distribution of species, genera and families in the different orders of Bryophyta

\begin{tabular}{|l|c|c|c|c|c|c|}
\hline & \multicolumn{2}{|c|}{ Families } & \multicolumn{2}{c|}{ Genera } & \multicolumn{2}{c|}{ Species } \\
\hline Orders & Number & $\mathbf{\%}$ & Number & $\mathbf{\%}$ & Number & $\%$ \\
\hline Hypnales & 8 & 33,3 & 13 & 29,5 & 17 & 24,3 \\
\hline Dicranales & 4 & 16,7 & 9 & 20,5 & 24 & 34,3 \\
\hline Hookeriales & 3 & 12,5 & 4 & 9,1 & 4 & 5,7 \\
\hline Bryales & 1 & 4,2 & 6 & 13,6 & 11 & 15,7 \\
\hline Pottiales & 1 & 4,2 & 4 & 9,1 & 4 & 5,7 \\
\hline Orthotricales & 1 & 4,2 & 2 & 4,5 & 3 & 4,3 \\
\hline Bartramiales & 1 & 4,2 & 1 & 2,3 & 2 & 2,9 \\
\hline Hedwigiales & 1 & 4,2 & 1 & 2,3 & 1 & 1,4 \\
\hline Rhizogoniales & 1 & 4,2 & 1 & 2,3 & 1 & 1,4 \\
\hline Isobryales & 1 & 4,2 & 1 & 2,3 & 1 & 1,4 \\
\hline Funariales & 1 & 4,2 & 1 & 2,3 & 1 & 1,4 \\
\hline Polytrichales & 1 & 4,2 & 1 & 2,3 & 1 & 1,4 \\
\hline Total & 24 & 100,0 & 44 & 100,0 & 70 & 100,0 \\
\hline
\end{tabular}

Table 3 Distribution of species in the different taxonomic groups

\begin{tabular}{|l|c|c|c|c|}
\hline \multirow{2}{*}{ Families } & \multicolumn{2}{|c|}{ Genera } & \multicolumn{2}{c|}{ Species } \\
\cline { 2 - 5 } & Number & $\mathbf{\%}$ & Number & \% \\
\hline Bryaceae & 6 & 13,6 & 11 & 15,7 \\
\hline Pottiaceae & 4 & 9,09 & 4 & 5,7 \\
\hline Calymperaceae & 3 & 6,82 & 8 & 11,4 \\
\hline Dicranaceae & 3 & 6,82 & 6 & 8,6 \\
\hline Hypnaceae & 3 & 6,82 & 4 & 5,7 \\
\hline Orthotrichaceae & 2 & 4,55 & 3 & 4,3 \\
\hline
\end{tabular}




\begin{tabular}{|l|c|c|c|c|}
\hline Neckeraceae & 2 & 4,55 & 3 & 4,3 \\
\hline Thuidiaceae & 2 & 4,55 & 3 & 4,3 \\
\hline Erpodiaceae & 2 & 4,55 & 2 & 2,9 \\
\hline Hookeriaceae & 2 & 4,55 & 2 & 2,9 \\
\hline Meteoriaceae & 2 & 4,55 & 2 & 2,9 \\
\hline Fissidentaceae & 1 & 2,27 & 8 & 11,4 \\
\hline Bartramiaceae & 1 & 2,27 & 2 & 2,9 \\
\hline Pterigynandraceae & 1 & 2,27 & 2 & 2,9 \\
\hline Rhacocarpaceae & 1 & 2,27 & 1 & 1,4 \\
\hline Rhizogoniaceae & 1 & 2,27 & 1 & 1,4 \\
\hline Trachypodaceae & 1 & 2,27 & 1 & 1,4 \\
\hline Funariaceae & 1 & 2,27 & 1 & 1,4 \\
\hline Daltoniaceae & 1 & 2,27 & 1 & 1,4 \\
\hline Pilotrichaceae & 1 & 2,27 & 1 & 1,4 \\
\hline Amblystegiaceae & 1 & 2,27 & 1 & 1,4 \\
\hline Pterobryaceae & 1 & 2,27 & 1 & 1,4 \\
\hline Sematophyllaceae & 1 & 2,27 & 1 & 1,4 \\
\hline Polytrichaceae & 1 & 2,27 & 1 & 1,4 \\
\hline Total & 44 & 100 & 70 & 100,0 \\
\hline
\end{tabular}

\section{Discussion}

Bryophytes are ancient, rather inconspicuous and poorly understood plants [2]. Bryophytes are the first plants to have diverged within the Embryophytes. They are only partially emancipated from the aquatic environment [43].

The floristic inventory has shown that the collections of bryophytes in the herbaria of Senegal are very diversified. The comparative analysis with the floras of the countries of the sub-region, the latter is less rich in terms of species. Indeed, this study is the first one carried out in this sense to better know the bryology of Senegal. The dominance of mosses is also visible in many other floras such as the checklist of Madagascar [44], Reunion Islands [4, 5, 7, 1], Mauritius [27]; South Africa [24, 51, 41, 38, 39, 40, 42, 34, 49], the moss and liverwort flora of Kenya [17, 18], the flora of Zimbabwe [6, 25], that of Cape Verde [8, 32, 45]. The dominance of the orders Hypnales, Dicranales and Hookeriales is a feature of several floras around the world: Madagascar [44], the moss and liverwort flora of Kenya [17, 18], the flora of Zimbabwe $[6,25]$. Bryaceae, Pottiaceae, Calymperaceae, Dicranaceae and Hypnaceae are the most widely represented. This is a characteristic of tropical bryological floras. The richness of the IFAN herbarium collection is due to the fact that it is a regional level herbarium receiving a lot of samples from African countries (French Guinea, Chad, Gabon, Uganda, Sao Tome and Principe) and even outside the African continent (Guadeloupe). Contrary to the collection of the DAKAR herbarium, the weakest one, which hosts only the samples collected in Senegal. Bryophytes in Senegal have not been the object of specific studies or collection missions. Compared to other African floras, this one is similar with a strong representation of mosses on liverworts: Guinea Bissau [54], Guinea Conakry [47, 56] and African floras: from Cote d'ivoire [9], Nigeria [28, 36], Sierra Leona[31], Central Africa [10], Uganda [13], Rwanda and Zaire [15, 11, 13, 32], Seychelles[43, 22], Egypt [29, 30] and Madagascar [26].

\section{Conclusion}

This work has made it possible to list all the bryophyte species potentially present or collected in Senegal. It shows in particular that knowledge on the bryophytes of Senegal is dispersed with three lists of flora. This flora is dominated by the Bryophyta in terms of families, genera and species. Three orders dominate in the Bryophyta: Hypnales, Dicranales and Hookeriales. Within the Bryophyta, the Bryaceae, Pottiaceae, Calymperaceae, Dicranaceae and Hypnaceae are dominant. Fissidens, Calymperes, Gemmabruym and Bryum are more diverse in the mosses. For the Bryophyta, 48 species were recorded, distributed in 39 genera, 21 families and 12 orders coming from 8 countries contrary to that of the weak DAKAR herbarium whose species are all of the country. The knowledge acquired in this work on the floristic composition of the herbaria should make it possible to better know the bryoflora of Senegal and to contribute to the knowledge of the plant diversity. 


\section{Compliance with ethical standards}

\section{Acknowledgments}

Our thanks to the IFAN and DAKAR herbaria and to the researchers and technicians for their help and availability.

\section{Disclosure of conflict of interest}

The authors declare no conflict of interest.

\section{References}

[1] Ah-Peng C, Bardat J. Check-list of the bryophytes of Reunion Island (France). Tropical Bryology. 2005; 26: 89-118.

[2] Ah-Peng C. Diversity, distribution and biogeography of bryophytes from the lava flows of the Piton de la Fournaise volcano (La Réunion, France). PhD University of La Réunion, Saint-Denis. 2007.

[3] Augier J. « Flora of bryophytes. Paris. 1966.

[4] Bescherelle E. Bryological flora of Reunion and other Austro-African islands of the Indian Ocean. Annales des Sciences Naturelles, Botanique, sér. 1879; 6(9): 291-380.

[5] Bescherelle E. Bryological flora of Reunion and other Austro-African islands of the Indian Ocean (Deuxième partie). Annales des Sciences Naturelles, Botanique, sér. 1880; 6(10): 233-332.

[6] Best EB. The Bryophytes of Zimbabwe - an annotated check-list. Kirkia. 1990; 13(2): 293-318.

[7] Bizot M. Mosses of Cape Verde Islands. Svensk Botanisk Tidskrift. 1969; 63(4): 441-454.

[8] Bizot M. African mosses collected by Mr Dénes Balázs. Acta Botanica Academiae Scientarum Hungaricae. 1973; 18: 7-28.

[9] Bizot M, Tixier P. Reliquiae Bizotianae. Bryological collections of R.P. Assel in the region of Abidjan (Ivory Coast). Annals of the University of Abidjan, Science and Techniques, Sci. Nat. et Biol. 1987; 22B: 33-58.

[10] Born S, Frahm JP, Pócs T. A new checklist of the mosses of Central Africa. Tropical Bryology. 1993; 8: 223-273.

[11] Buck WR. Taxonomic Results of the BRYOTROP expedition to Rwanda and Zaire. 24. Leskeaceae, Plagiotheciaceae, Entodontaceae, Sematophyllaceae, Hypnaceae (except Hypnum). TropicalBryology.1993; 8: 199-218.

[12] Buck WR, Goffinet B. Morphology and classification of mosses, pp. 71-123. In: Bryophyte Biology. Cambridge University Press: Cambridge. 2000.

[13] Bruggeman-Nannenga MA. Taxonomic Results of the BRYOTROP expedition to Rwanda and Zaire. 15. Fissidentaceae. Tropical Bryology. 1993; 8: 141-148.

[14] Bruggeman-Nannenga MA. Notes on Fissidens VII-IX. Journal of bryology. 2009; 31: 106-116.

[15] Chuah-Petiot MS. Bryophytes from the Saiwa Swamp National Park, Kenya. Tropical Bryology. 1996; 12: 63-74.

[16] Chuah-Petiot MS. Contribution to the bryoflora of Kenya. Tropical Bryology. 2001; 20: 31-37.

[17] Chuah-Petiot MS. Mosses, Liverworts and Hornworts of Kenya p. 273. An illustrated guide with descriptions and figures of over 300 species and keys for identification. Edited by the author. 2003.

[18] Chuah-Petiot MS, Pócs T. East African bryophytes XIX. A contribution to the bryoflora of Kenya. Acta Botanica Hungarica. 2003; 45: 53-64.

[19] Crosby MR, Magill RE. Index of Mosses 1990-1992. Monographs in Systematic Botany from the Missouri Botanical Garden. 1994; 50: 1-87.

[20] Crosby MR, Magill RE. Index of Mosses 1993-1995. Monographs in Systematic Botany from the Missouri Botanical Garden. 1997; 62: 1-106.

[21] Crosby MR, Magill RE, Bauer CR. Index of Mosses 1963-1989. Monographs in Systematic Botany from the Missouri Botanical Garden. 1992; 42: 1-646.

[22] De Sloover JL. Bryophytes of La Digue (Seychelles). Cryptogamie: Bryologie, Lichénologie. 1995; 16: 213-217. 
[23] Diop D. Bryophytes of Senegal: structure of the flora and morpho-anatomical characterization. PhD University Cheikh Anta DIOP of Dakar. 2019; 291.

[24] Dixon HN, Wager HA. New and noteworthy mosses from South Africa. Transactions of the Royal Society of South Africa. 1929; 18: 247-261.

[25] During HJ, Moyo C. The diaspore bank of bryophytes in a Zimbabwean savanna. Haussknechtia Beiheft. 1999; 9: 111-114.

[26] Een G. Mosses from Africa 3 sensu Index Muscorum. (Manuscript on disk, dated 22/07/1993). 1993.

[27] Een G. Bryophytes collected in Mauritius by Gunnar Erdtman. Tropical Bryology. 2000; 18: 87-90.

[28] Egunyomi A. New records for the moss flora of Nigeria. Bryologist. 1984; 87: 369-370.

[29] El-Saadawi W, Badawi A. The moss flora of Egypt. I. Order Pottiales. Publications of Cairo University Herbarium. 1977; 7-8: 181-206.

[30] El-Saadawi W, Shabbara HM, Refai MS, Abou-Salama UY. Mosses of different phytogeographical territories of Egypt. Bocconea. 2003; 16: 133-146.

[31] Enroth J. The mosses collected by Vladi Marmo in Sierra Leone, 1953-55. Hikobia. 1996; 12: $137-146$.

[32] Frahm JP. Manual of tropical bryology. Tropical Bryology. 2003; 23: 195.

[33] Frahm JP, Lindlar A, Sollman P, Fischer E. Bryophytes from the Cape Verde Islands. Tropical Bryology. 1996; 12: 123-154.

[34] Frey W. Morphologie and Anatomie der Laubmoose. Advances in Bryology. 1981; 1: 3996477014.

[35] Goffinet B, Buck W, Shaw AJ. Morphology and Classification of Bryophytes in Book Bryophyte Biology Ed. 2nd Cambridge University Press. 2009.

[36] Jones EW. Bryophytes of forest and savanna in northern Nigeria. Cryptogamie: Bryologie, Lichénologie. 1985; 6: 259-277.

[37] Kürschner H, Parolly G. Life forms and adaptations for water conduction and water storage of the epiphytic bryophytes of northern Peru (Amazonian Lowlands, Cordillera Oriental, Cordillera Central). Nova Hedwigia. 1998; 67(3-4): 349-379.

[38] Magill RE. Bryophyta Part I. Mosses. Fasc I. Sphagnaceae-Grimmiaceae. Flora of Southern Africa. O. A. Leistner. Rep. of South Africa. 1981; 204.

[39] Magill RE. Bryophyta. Part 1. Mosses. Fasc. II. Gigaspermaceae - Bartramiaceae in Flora of Southern Africa ed. O.A. Leistner, Republic of South Africa. 1987.

[40] Magill RE. Musci Austro-Africana III. Alpine mosses of Lesotho. Journal of Bryology. 1987; 14: 527-530.

[41] Magill RE, Schelpe EACLE. The bryophytes of Southern Africa, an annotated checklist. Memoirs of the Botanical Survey of South Africa. 1979; 43: 1-39.

[42] Magill RE, van Rooy J. Bryophyta. Part 1. Mosses. Fasc. III. Erpodiaceae - Hookeriaceae in Flora of Southern Africa ed. O.A. Leistner, Republic of South Africa. 1998.

[43] Manneville 0. Bryophytes: mosses, sphagnum mosses, liverworts: Particularities and biological cycles, various groups, ecology Station Alpine Joseph Fourier - UJF Grenoble. 2011; 10.

[44] Marline L, Andriamiarisoa RL, Bardat J, Chuah-Petiot M, Hedderson TAJ, Reeb C, Strasberg D, Wilding N, Ah-Peng C. Checklist of the bryophytes of Madagascar. Cryptogamie, Bryologie. 2012; 33: 199-255.

[45] Muhle H. A checklist of mosses of the Cape Verde Islands. Courier Forschungsinstitut Senckenberg. 1982; 52: 277281.

[46] Onraedt M. Bryophytes of the mascareno-malagasy islands and Seychelles III. Hepaticae: Bazzania. Bulletin du Jardin Botanique National de Belgique. 1977; 47: 139-144.

[47] O'Shea BJ. Checklist of the mosses of sub-Saharan Africa (version 5, December 2006). Tropical Bryology Research Reports. 2006; 6: 1.255. 
[48] Petit E. Extracted from: Keys for the determination of the families and genera of the pleurocarpous mosses (Musci) of Africa. Bull. Jard. Bot. Nat. Belg. 48: 135-181. 1978. Translated by M.J.Wigginton, 36 Big Green, Warmington, Peterborough, PE and C.R. Stevenson, 111 Wootton Road, King's Lynn, Norfolk, PE

[49] Perold SM. Hepatophyta Part 1. Marchantiales. Fasc.1. Marchantiidae. Flora of Southern Africa (ed. by O.A. Leistner). National Botanical Institute, Pretoria. 1999.

[50] Potier de la Varde R. Mousses du Gabon. Saint-Lo, R. Jacqueline. 1936.

[51] Sim TR. The Bryophyta of South Africa. Transactions of the Royal Society of South Africa 15: 1- 475. 1926.

[52] Söderström L, Hagborg A, von Konrat M, Bartholomew-Began S, Bell D, Briscoe L, Brown E, Cargill DC, Costa DP, Crandall-Stotler BJ, Cooper ED, Dauphin G, Engel JJ, Feldberg K, Glenny D, Gradstein SR, He XL, Heinrichs J, Hentschel J, Ilkiu-Borges AL, Katagiri T, Konstantinova NA, Larrain J, Long DG, Nebel M, Pócs T, Felisa-Puche F, Reiner-Drehwald E, Renner MAM, Sass-Gyarmati A, Schafer-Verwimp A, Segarra- Moragues JG, Stotler RE, Sukkharak P, Thiers BM, Uribe J, Váňa J, Villarreal JC, Wigginton M, Zhang L, Zhu RL. World checklist of hornworts and liverworts. PhytoKeys. 2016; 59: 1.828.

[53] Vitt DH. Classification of the Bryopsida. In: R.M. Schuster (ed.) new Manual of Bryology (ed R.M. Schuster). The Hattori Botanical Laboratory Nichinan, Japan. 1984.

[54] Wigginton MJ. Checklist and distribution of the liverworts and hornworts of sub-Saharan Africa, including the East African Islands. Tropical Bryology Research Reports. 2002; 3: 1-88.

[55] Wigginton MJ. Checklist and distribution of the liverworts and hornworts of Sub-Saharan Africa, including the East African Islands (edition 2, September 2004). Tropical Bryology ResearchReports. 2004; 5: 1-102.

[56] Wigginton MJ. Checklist and distribution of the liverworts and hornworts of Sub-Saharan Africa, including the East African Islands. Edition 3. Tropical Bryology Research Reports. 2009; 7: 1.114. 